\title{
Upcycling: An emerging textile waste management strategy for the fashion industry
}

\author{
Muskan Agrawal ${ }^{1} \mid$ Latika Bhatt ${ }^{2}$
}

${ }^{1}$ National Institute of Fashion Technology, Master of Design Student, Strategy Design, Navi Mumbai, India

${ }^{2}$ National Institute of Fashion Technology, Assistant Professor, Textile Design, Navi Mumbai, India

To Cite this Article

Muskan Agrawal and Latika Bhatt, "Upcycling: An emerging textile waste management strategy for the fashion industry", International Journal for Modern Trends in Science and Technology, 6(9S): 161-165, 2020.

Article Info

Received on 25-August-2020, Revised on 08-September-2020, Accepted on 12-September-2020, Published on 18-September-2020.

\section{ABSTRACT}

The fashion industry is the second largest polluting industry in the world. Different fashion cycles provide various options in the market, which leads to the rising concern of the environmental impact of the industry. Wastewater, carbon, and textile waste are different types of waste being generated by the industry. Textile waste is generated in two phases i.e. during production (textile leftovers) and post-production (discarded textiles). Therefore, it is important to look at the environmental impact of the textile industry and take initiatives to reduce the overall impact on the environment. The purpose of the research is to study how a couture brand manages the textile waste generated during the production and to generate ideas to reuse them. The couture brand in which the study was conducted was Shriya Som. The waste management strategy of the Couture brand Shriya Som was studied and analyzed in terms of waste generation and its reuse. The amount of waste being generated by the brand daily was evaluated and how much is reused and how much was going to landfill. Strategy to utilize the leftover fabrics were developed keeping in mind the brand identity. This study gives an overall perspective of textile waste management strategies being adopted by the industry. Also suggests ideas to reuse textile waste. It was found that most of the leftovers can be creatively reutilized in the product line itself to reduce or completely zero down the waste going to the landfills.

KEYWORDS: Re-use, surface embellishments, upcycling, textile waste management, sustainability

\section{INTRODUCTION}

The apparel market contributes 2 percent of the world's GDP. The apparel industry is the second largest polluting industry in the world. About 15\% of fabric intended for clothing ends up on the cutting room floor. Fast fashion is an approach to design and create fashion trends quickly and cheaply available for all consumers. Due to fast fashion consumption, fabric waste has become a significant problem for the fashion industry in terms of growing waste management costs and its impact. The industry accounts for high carbon emissions, wastewater production, and large amounts of landfill waste. To prevent the impact the industry is taking measures to consume the waste back in the production process. One of the strategies that the industry is adopting to reduce textile waste is upcycling. Upcycling is a process of converting waste or useless materials into better quality or higher value products. The goal of upcycling is to use existing material to prevent the wastage of potentially useful materials. Upcycling is greener and environmentally better way of recycling. The consumption of new materials for new products is reduced by consuming already existing materials, which results in the reduction of 
energy usage, and other impacts. This paper presents the findings on the advantage of the upcycling process and the different brands adopting upcycling as their strategy to manage the textile waste. The paper also presents the upcycling textile waste project done with an haute couture brand Shriya Som and suggests a strategy to utilize the leftover fabrics in the existing garment itself keeping brand identity in mind.

\section{METHODOLOGY}

\section{A. Secondary study:}

The study started with Secondary Research, which included desk research, where the study was conducted on various ways of textile waste management and waste management initiatives by various brands. Existing Research papers, Articles, blogs were referred for the study.

- Study on existing sustainable brands

A study was conducted to research on various sustainable brands that are already existing to understand the different sustainable initiative by various brands.

\section{B. Primary Study}

Primary Research was conducted through unstructured interviews within an haute couture brand Shriya Som to understand the fabric waste generation and waste management within brand management.

- Type of waste generation at Shriya Som studio

A study was conducted within the brand to understand the type of waste and the amount of waste being generated within the brand.

- Textile waste management at Shriya Som studio

A study was conducted within the brand to understand how the waste is being managed by the brand, whether it goes to landfill or it is being reused.

\section{Ideation and implementation:}

In this stage, the waste was collected and segregated. Then the fabric was used:

- To develop prototypes using waste fabrics Utilizing the prototypes on to the garments as surface embellishments.

\section{RESULTS AND DISCUSSION}

A. Study on various sustainable brands

Table I Analysis of sustainable brands

\begin{tabular}{|c|c|c|c|}
\hline & Type of Fabric & Waste management & Product categories \\
\hline $\begin{array}{l}\text { Patch over } \\
\text { Patch }\end{array}$ & Scraps and textile wastes & Menswear, shirt-suit waste is used for bags & Clothing and Bags \\
\hline Doodlage & $\begin{array}{l}\text { Rejects and scraps, recycled } \\
\text { cotton polyester, bamboo } \\
\text { fabric, and corn fabric }\end{array}$ & $\begin{array}{c}\text { Leftover fabrics from their unit are used to make tote } \\
\text { bags }\end{array}$ & $\begin{array}{l}\text { Women's wear Men's wear } \\
\text { Accessories }\end{array}$ \\
\hline $\begin{array}{l}\text { Priyanka } \\
\text { Raajiv }\end{array}$ & $\begin{array}{l}\text { Handwoven fabric, leftovers } \\
\text { from their production unit. }\end{array}$ & $\begin{array}{l}\text { The rejects and leftovers textiles from their unit are } \\
\text { upcycled and appliqued seamlessly, incorporating } \\
\text { them into new designs. }\end{array}$ & Bridal and ethnic wear \\
\hline $\begin{array}{l}\text { Wearelabel } \\
\text { ess }\end{array}$ & $\begin{array}{l}\text { Handwoven fabric, handloom } \\
\text { fabrics leftover waste from the } \\
\text { weavers in Bhagalpur }\end{array}$ & $\begin{array}{l}\text { They make an upcycled collection with the waste } \\
\text { generated from the collection. }\end{array}$ & $\begin{array}{l}\text { Accessories, earrings, } \\
\text { key-chain, ties, belts, and } \\
\text { patch bralettes }\end{array}$ \\
\hline Ka Sha & $\begin{array}{l}\text { Natural fibers, recycled and } \\
\text { repurposed materials }\end{array}$ & $\begin{array}{l}\text { They make Patchwork jacket, accessories, footwear, } \\
\text { and rugs, for their 'Heart-to-Haat' initiative, by } \\
\text { upcycling the waste from their previous line. }\end{array}$ & $\begin{array}{l}\text { Clothing, Rugs, Bags, } \\
\text { Utility, Scarf }\end{array}$ \\
\hline $\begin{array}{l}\text { Amit } \\
\text { Aggarwal }\end{array}$ & $\begin{array}{l}\text { Handwoven organic textiles, } \\
\text { recycled materials }\end{array}$ & $\begin{array}{l}\text { The brand contributes to using recycled and upcycled } \\
\text { fabrics. }\end{array}$ & Women's wear Men's wear \\
\hline $\begin{array}{l}\text { I was a } \\
\text { Saree }\end{array}$ & $\begin{array}{l}\text { Old sarees from the Mumbai } \\
\text { market }\end{array}$ & $\begin{array}{l}\text { They donate their leftover to the NGO, which uses the } \\
\text { fabric to make sanitary napkins and other products }\end{array}$ & $\begin{array}{c}\text { Clothes, Jewelry, } \\
\text { Accessories, Shoes, Bags }\end{array}$ \\
\hline $\begin{array}{l}\text { Paromita } \\
\text { Banerjee }\end{array}$ & $\begin{array}{l}\text { Natural fabrics like Ikat, } \\
\text { Jamdani, Khadi }\end{array}$ & $\begin{array}{l}\text { Create different accessories single edition kimonos, } \\
\text { and with the smaller pieces, tassels, and buttons. }\end{array}$ & $\begin{array}{l}\text { Women's clothing, Sarees, } \\
\text { Bags, Khaata (notebook) }\end{array}$ \\
\hline $\begin{array}{l}\text { House of } \\
\text { Wandering } \\
\text { silk }\end{array}$ & $\begin{array}{l}\text { Upcycled fabric, handmade } \\
\text { and vintage materials }\end{array}$ & They make accessories from the leftovers. & $\begin{array}{l}\text { Women's clothing, } \\
\text { Accessories, Scarfs, } \\
\text { shawls, and wraps }\end{array}$ \\
\hline $\begin{array}{l}\text { Pomogren } \\
\text { ade }\end{array}$ & $\begin{array}{l}\text { fabrics are locally sourced } \\
\text { and produced by a fair-trade } \\
\text { manufacturing unit. }\end{array}$ & $\begin{array}{c}\text { They use waste fabric from their unit to make a varied } \\
\text { range of accessories }\end{array}$ & Clothing and accessories \\
\hline Latasita & Old Sarees & $\begin{array}{l}\text { The leftover scraps are recycled, those scraps which } \\
\text { they can't use, they donate them to Goonj, an NGO } \\
\text { that makes sanitary napkins }\end{array}$ & Women's clothing, \\
\hline
\end{tabular}



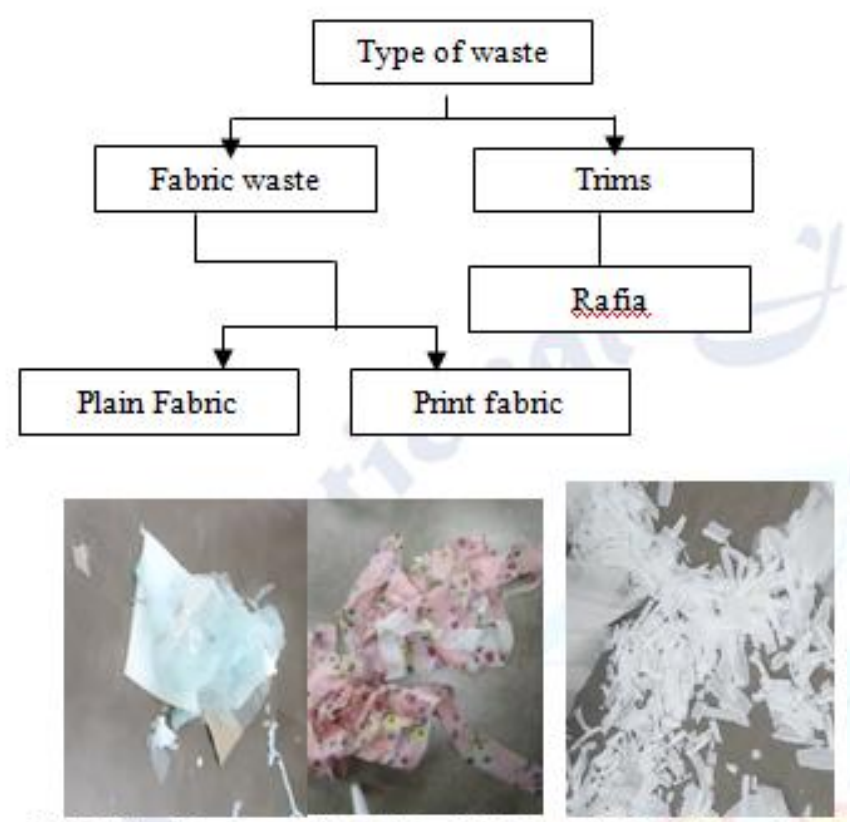

Fig 1 Plain fabric leftovers

Fig 2 Print fabric leftovers

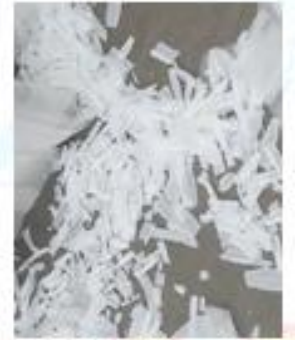

Fig 3 Raffia trims leftovers

- Textile waste management at Shriya Som studio

All the leftovers from printed fabric and trims directly go to landfill. The plain fabric leftovers get upcycled within the brand. If the leftover is around half-meter or more. They make a ruffle dress and cabbage dress out of that. If the left-over fabric is less than that, then it is kept for alteration. The very small pieces (katran) goes to landfill. Even after reusing the leftovers for new garments and alteration, fabric leftovers were ending to the landfill. On daily basis $1-2$ bags of size $30 \times 50$ inches approx. was ending to landfill. For reducing the wastage of materials, first, all the materials were collected, it was then segregated according to types, like printed fabric, plain fabric, and trims.

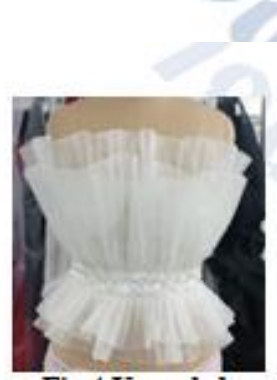

Fig 4 Upcycled cabbage top

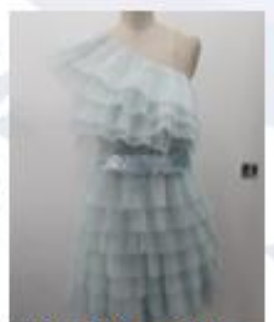

Fig 5 Upcycled cabbage dress
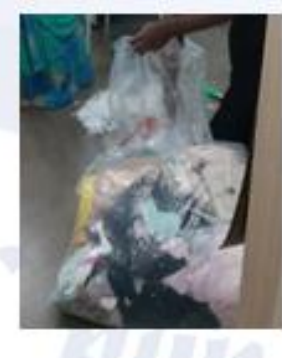

USP of the brand, from their embroidery techniques, the simplest embroidery technique was used which is called "Markan". With the help of markan techniques, outlines were made around the flowers in the leftover print fabric, and taken out by cutting them with the help of scissors.
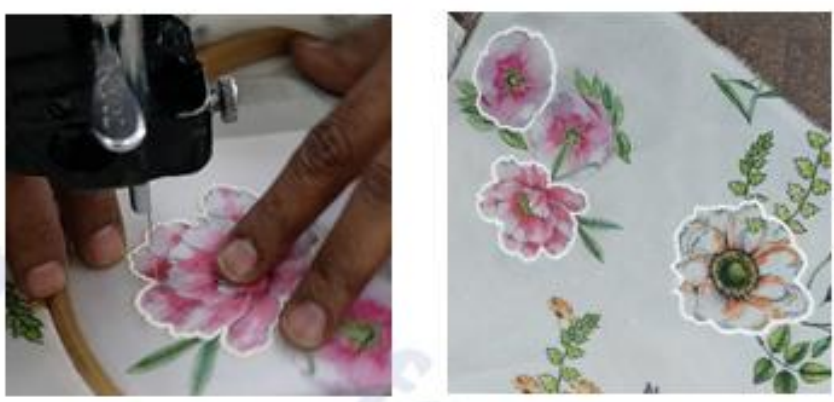

Fig 7 Markan embroidery on printed leftover fabric

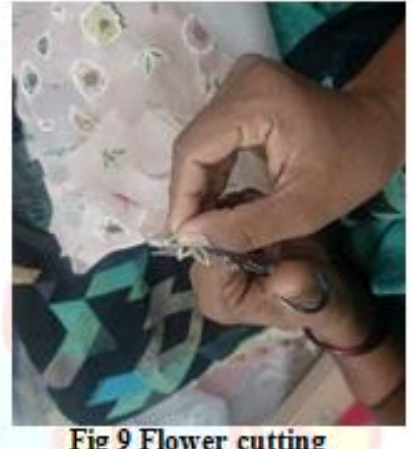

Fig 9 Flower cutting

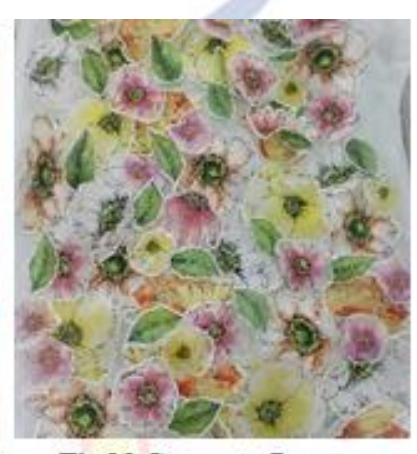

Fig 10 Cut-outs flowers

Even after using the flowers the plain part in the printed were getting wasted, to use that small circles were made in the plain area, and markan was done on the border of circles. Then those flowers were taken out by cutting them with the help of scissors, and latkan (tassels) were made using them.

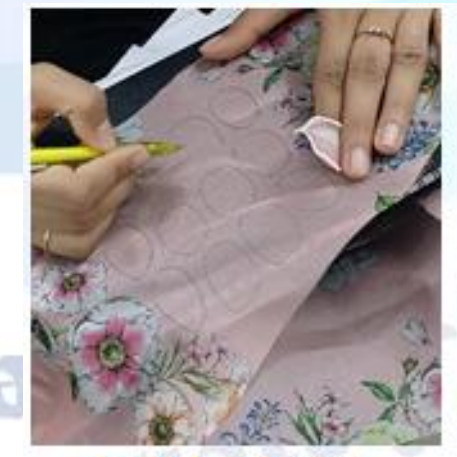

Fig 11 Oval drawing

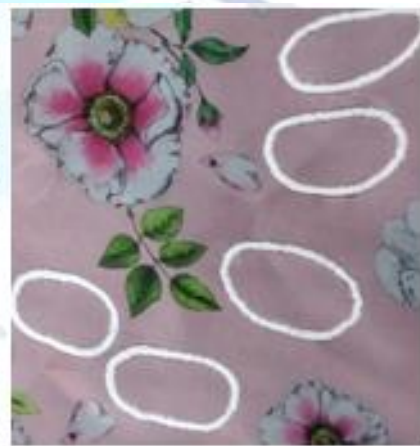

Fig 12 Oval with markan embroidery

- Prototypes development using Print fabric waste

Since the printed fabrics were not being utilized, so the prototypes were made to utilize them Flowers and Embroidery technique is the signature and 

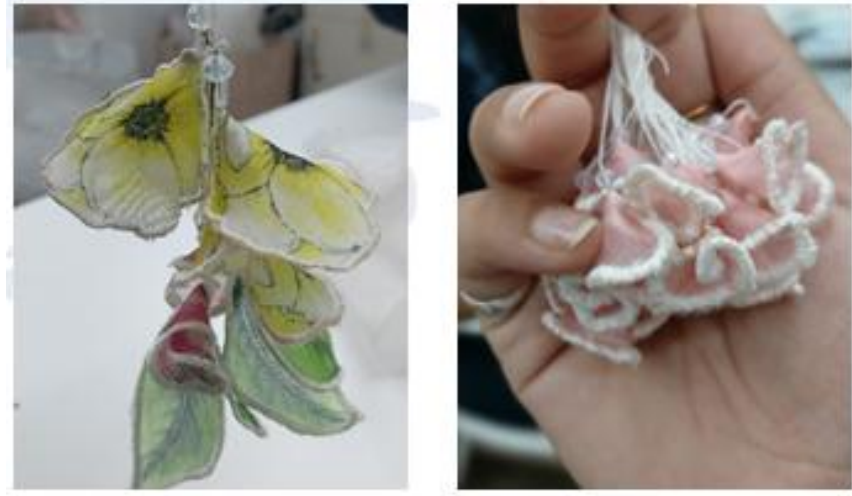

Fig 13 (a) \& (b) Upcycled latkan

- Prototype development using Plain fabric waste

- Few 3d flower prototypes were made by using the plain fabric which was still ending up to landfill even after the utilization. Which can be used as surface embellishments in the garments.

- Utilizing the prototypes on to the garments as surface embellishments

The print prototypes were used to give the 3D effect on their prints collection, as they use various embroidery techniques to create textures and 3D effect in their couture garment. The flowers were attached in the garments using their boond embroidery technique. The latkan (Tassels) made from ovals were used in scarfs
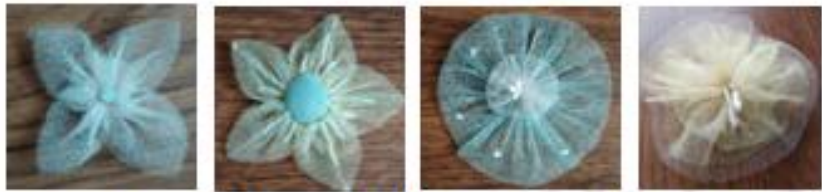

Figure 14 (a), (b), (c) \& (d) Prototype ideas for plain fabric utilization.

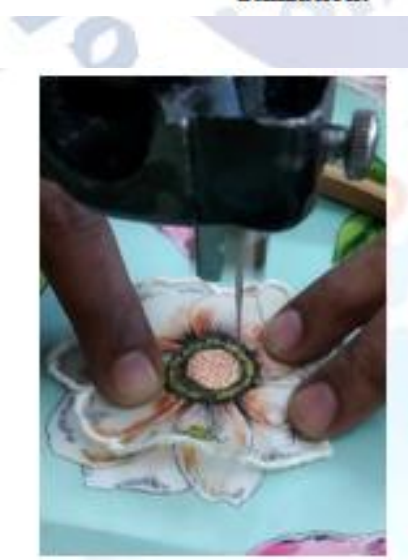

Fig 15 Flower adding in the garment with boond embroidery
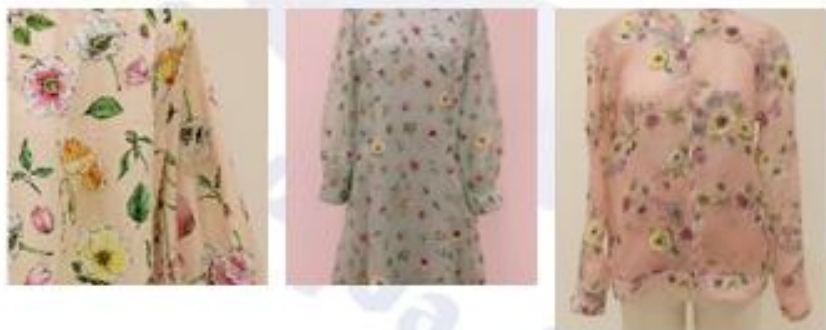

Fig 16 (a), (b) \& (c) Garments with upcycled flowers
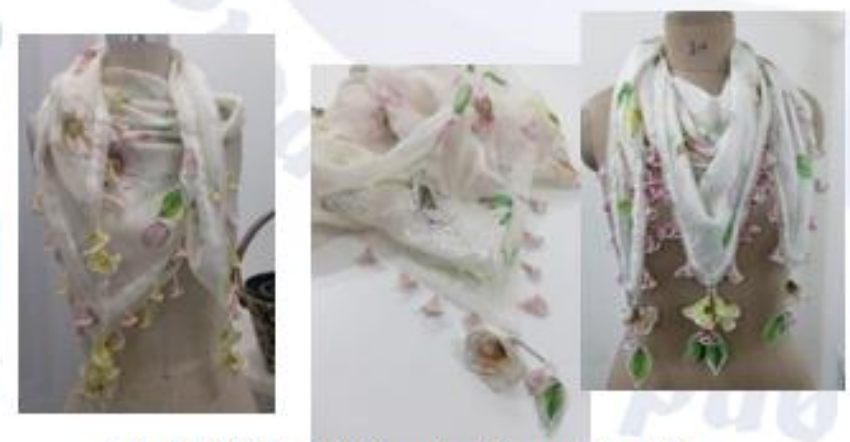

Fig 17 (a), (b) \& (c) Scarfs with upcycled latkan

Here are few ideas to utilize 3D flowers made from plain fabric:

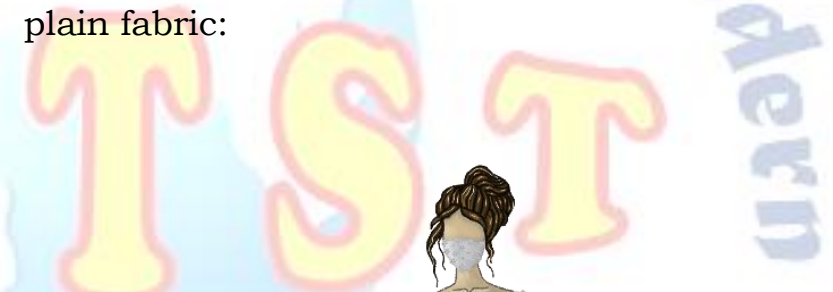




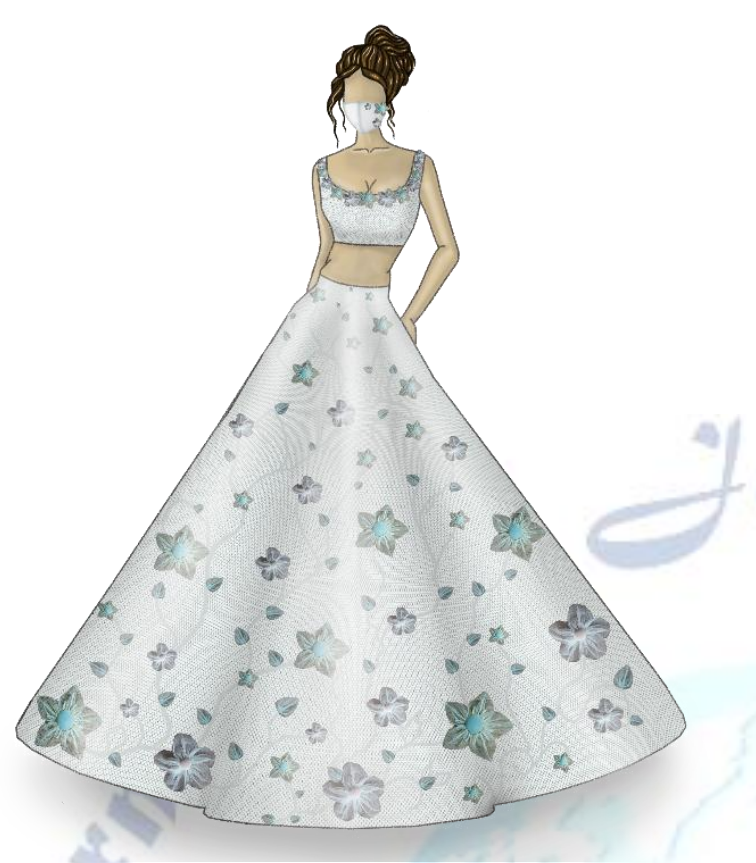

Fig 18 (a) \& (b) Illustrated ideas to utilize Plain fabric 3D flowers

\section{Conclusion}

Most of the brands are choosing upcycling as their textile waste management strategy. Even the new brands are coming up with upcycling as their main technique of the design, production, and fabric leftover management. Upcycling allows the utilization of the largest possibility of the amount of textile waste to be given new value. Upcycling can be an incremental step towards achieving zero waste, and the problems associated with textile waste can be solved by upcycling those waste, as upcycling is not only reusing the materials, but it is given higher value to the material. Upcycling has an environmental benefit as it reduces or at least delays the additional amount of trash going to landfills. Most of the fabric leftovers can be utilized by upcycling them and utilizing in the product line itself to reduce the amount of trash going to landfills, if utilized in a creative way it can also lead to achieving zero waste.

\section{REFERENCES}

[1] Akriti Shakya, (2016) Integrated waste minimization techniques in apparel design: a sustainable perspective

[2] Cara Smusiak, (2010) What is Upcycling? https://naturallysavvy.com/live/what-is-upcycling/

[3] Robin Murray, (2002) Zero Waste, Greenpeace Environmental Trust publication

[4] M. D. Teli1, Sanket Valia1, Kavita Kaduland Monali Dahale2, (2015) Upcycling of Textile Materials

[5] https://indific.com/upcycling-fashion-india-320/

[6] https://www.vervemagazine.in/tag/patch-over-patch
[7] https://www.facebook.com/pg/patchoverpatch/about/?r ef=page_internal

[8] https://www.indiatoday.in/mail-today/story/fashion-recl aimed-1621936-2019-11-23

[9] https://www.thehindu.com/life-and-style/this-diwali-upc ycle-your-festive-style/article29736250.ece

[10] https://refash.in/blogs/design-process/i-was-a-sari-desi gn-story

[11] https://refash.in/blogs/brand-story/we-are-labeless-bra nd-story

[12] https://refash.in/blogs/interviews-with-brands/interview -with-kavisha-parikh

[13] https://www.youthkiawaaz.com/2017/01/doodlage-turn s-waste-to-fashion/

[14] https://www.causeartist.com/meet-doodlage-the-ethical-f ashion-brand-reversing-the-design-process/

[15] https://www.popxo.com/2017/09/doodlage-sustainable-f ashion-brand-interview/

[16] https://www.currentmoodmag.com/2017/07/17/kriti-tul a/

[17] https://www.cnbctv18.com/videos/economy/doodlage-tu rning-industrial-wastes-into-fashion-642971.htm

[18] https://www.facebook.com/pg/Priyanka-Raajiv-5132442 $78750653 /$ photos/?ref=page_internal

[19] https://www.vogue.in/portfolio/brand/portfolio-priyanka -raajiv/

[20] https://www.priyankaraajiv.com/

[21] https://www.wedmegood.com/photos/p-photo-3xxels7

[22] https://www.facebook.com/pg/wearelabeless/photos/?re $\mathrm{f}=$ page_internal

[23] https://so.city/delhi/article/check-out-the-preview-of-thi s-ethical-label-less-brands-1st-collection-in-champa-gali

[24] https://apparelresources.com/fashion-news/features/kasha-india-redefining-norms-sustainability-conscious-colla borations/

[25] https://www.livemint.com/

[26] https://www.thehindu.com/features/metroplus/fashion/ karishma-shahani-her-design-yatra/article6365198.ece

[27] https://www.forbesindia.com/article/30-under-30/30-un der-30-karishma-shahani-khan-desi-by-design/42219/1

[28] https://www.news 18.com/news/lifestyle/sustainability-is -the-future-textile-is-at-the-heart-of-it-amit-aggarwal-144 9915.html

[29] https://www.indulgexpress.com/fashion/new-launches/ 2019/sep/20/amit-aggarwals-aw-19-collection-employs-f abric-made-from-recycled-pet-bottles-18259.html

[30] http://www.folk-ark.com/house-of-wandering-silk

[31] https://www.wanderingsilk.org/purpose-vision-values

[32] https://thevoiceoffashion.com/fabric-of-india/crafts-andtextiles / paromita-banerjee-the-textile-whisperer-of-kolkat a-3091

[33] https://www.freepressjournal.in/cmcm/reinvent-is-upcyc ling-the-new-fashion-buzzword

[34] https://lbb.in/bangalore/pomogrenade-ethical-clothing-b rand/

[35] https://www.pomogrenade.com/pages/about-us

[36] https://www.pomogrenade.com/pages/closing-the-loop 